\title{
DICTIONARIES OF CRITICALLY ENDANGERED LANGUAGES: FOCUS ON USERS
}

\author{
OLGA NIKOLAJEVNA IVANISHCHEVA* \\ Faculty of Philology, Journalism and Intercultural Communication, \\ Murmansk Arctic State University in Murmansk, Russia
}

\begin{abstract}
IVANISHCHEVA, Olga N.: Dictionaries of Critically Endangered Languages: Focus on Users. Journal of Linguistics, 2016, Vol. 67, No 1, pp. 73 - 86.
\end{abstract}

\begin{abstract}
The article describes specific features of dictionaries of endangered languages from the perspective of their user. Dictionaries of the Saami language - the language of the indigenous minority of the North - are used to describe the anthropocentric, cognitive and pragmatic approach to lexicographical description of culture. The article shows that the focus on the dictionary user becomes especially critical for the endangered languages. It proves that the purpose of such dictionaries is not only to preserve the knowledge that the speakers of the endangered language and bearers of the culture still keep, but also to revitalize this knowledge. The article states that contemporary lexicography must consider several factors for making an endangered language dictionary: the present state of the language in the language community and the scope of background knowledge of a language speaker that represents everyday level of the world cognition by indigenous minority. The article shows that the most relevant type of dictionary for the endangered languages is both a learner's dictionary and a linguoculturological dictionary (active type). We emphasize that on the one hand the Saami dictionaries describe a culture that is often unknown even to most Saami culture bearers and on the other hand, the dictionaries are also intended for Saami who have no command of the native language. The peculiarities of the relevant dictionary comprise the fact that alongside the translation in the basic part of the dictionary there is a culturological commentary that as fully as possible reflects the knowledge of language speakers.
\end{abstract}

Key words: dictionary, endangered language, Saami language, lexicography

\section{INTRODUCTION}

One of notable tendencies in contemporary lexicography is the focus on the dictionary user. Taking their needs, interests and experience into account meets current requirements to linguistics on the whole. The anthropocentric tendency in the development of present scientific thought as well as the cognitive approach to language assume turning to human being as language speaker and culture bearer. With regard to endangered languages the accumulation and preservation of verbalized experience of spiritual and material life of people appears to be of immediate interest. Such a position shall allow not only to preserve the cultural baggage accumulated by language for the future generations, but also to understand people's mentality, which means to develop a correct strategy for its revitalization.

${ }^{*}$ Pri prepise vlastných mien z ruskej pravopisnej sústavy a pri uvádzaní bibliografických jednotiek a odkazov rešpektujeme medzinárodnú normu, ktorú uplatnila autorka štúdie. (pozn. red.) 


\section{RESEARCH SUBJECT AND APPROACHES}

The purpose of this paper is to prove that it is important to pay due regard to user of an endangered language dictionary from anthropocentric and cognitive-andpragmatic perspective. The paper develops the claim that focus on the dictionary user is especially important for endangered languages. At this it must be taken into account that dictionary user being an ethnos representative and claiming their nationality, observing the traditions and preserving their culture, often has no or limited command of the native language. Such a speaker knows certain terminological base which is required to master a craft and use everyday language with limited vocabulary. The dictionary purpose in this situation is not only to preserve what the speakers of an endangered language still remember, but also to revitalize this knowledge. From our point of view, the contemporary lexicography should take several aspects into account for dictionary making: who this dictionary is made for (anthropocentric aspect), what will this dictionary be used for (pragmatic aspect) and what skills the user shall need to use it (cognitive aspect). These factors, pointed out for lexicography of any language, have certain peculiarities, when we speak of endangered languages. We think that in connection with this the most suitable for the endangered languages is learner's and linguoculturological dictionary (dictionary of active type).

\section{RESEARCH METHODS}

We used the following methods of sociolinguistics for making Saami dictionaries: a field study, questionnaires, written surveys and interviews, expert survey and biographical approach (case study used to examine contemporary reallife). In our research we used the Saami archives and libraries of the Murmansk region. The descriptive method, componential analysis, definition analysis, continuous and random sampling were also used in our research.

\section{ACTIVE AND PASSIVE LANGUAGE COMPETENCE AS THE BASIS FOR CONTEMPORARY LEXICOGRAPHY}

As was repeatedly outlined by researchers making dictionaries of active type is gaining importance. The issue of dictionaries used for encoding and decoding (active and passive dictionary) arises almost in every lexicographical paper (see e.g.: Landau, 2001, p. 9; Gao, 2013; Nkomo, 2015; Schryver - Prinsloo, 2011).

For Lev V. Shcherba, for instance, it was evident that every pair of languages requires two explanatory (definition) foreign-native dictionaries - for Russians with explanations in the Russian language and for foreigners in their native languages. These four dictionaries for each pair of languages in the opinion of L. V. Shcherba 
would give an opportunity to read and understand foreign books and get to know the real faces of foreign words (Shcherba - Matusevich, 1993, p. 7). It is the division of bilingual dictionaries into active type (Russian-foreign for a Russian user, for instance) and passive type (foreign-Russian for a Russian user) that defines their tasks. The usefulness of a French-English dictionary for the Americans and FrenchEnglish for the French is discussed by Sidney Landau, for instance (2001, p. 9).

As L. V. Shcherba claims, the primary contrast in foreign languages teaching methodology is the opposition of teaching active language knowledge and teaching passive language knowledge. L. V. Shcherba wrote: "Teachers, who believe that one can learn to read only as much are they speak, unwittingly find themselves in a deceiving circle: in order to learn to read book one must learn to speak, but it turns out that in order to learn to speak one should read a lot" (Shcherba, 2002, p. 99).

According to Vladimir G. Gak, the purpose of a passive dictionary is to open up the meaning of a word when a translation within a certain context can be found by a reader himself based on their native language competence. Turning to an active dictionary the reader looks not for an explanation of a meaning of a word to be translated (they know it already), but for instructions, which would let them find an exact equivalent in the target language (Gak, 1995, p. 53). Thus, an active type dictionary shall present such a characteristic of a word that will allow not only to understand it in a given context, but to use it properly in one's own speech (Apresyan, 1999, p. 7). What is basically meant here is the grammatical and the semantic aspect of the issue. An active dictionary, in the opinion of V. G. Gak, for instance, shall show various semantic and grammatical changes that happen to the words as they go from a language system into speech (Gak, 1995, pp. 53 - 54).

The authors of Explanatory and Combinatory Dictionary of the Russian Language Igor A. Melchuyk and Alexandr K. Zholkovsky (Melchuyk Zholkovsky, 1984) emphasized the active character of their dictionary implying that their dictionary is a dictionary of synthesis, focused on the needs of the speaker (writer).

The ideas of L. V. Shcherba were put into practice among other things in making of an active dictionary of Russian language, theoretical basis of which is presented in the monograph Prospect of Active Dictionary of the Russian language (Apresyan, V. - Apresyan, Yu. - Babaeva - Boguslavskaya - Galaktionova - Glovinskaia - Iomdin - Krylova - Levontina - Ptentsova - Sannikov - Uryson, 2010). In the opinion of Yurij D. Apresyan, the basic formula of a passive dictionary is many words, minimum information for each word, sufficient for its understanding in a random context. The basic formula of an active dictionary is far less words but whenever possible full information about each word, required for its correct use in speaker's own speech. This task is solved by supplying the dictionary with as full as possible information about all sides of a word that are essential for correct speech, its forms and meanings, its stylistic, syntactic and selectional properties in various 
meanings, pragmatic conditions of its use, its synonyms, antonyms, converse terms, derivatives, counterparts and thematically-linked words, forming its "lexical environment", about phrasemes, which it is included into, etc. The attention of the authors of the active dictionary of the Russian language is focused on providing such information that would include contextual use of a word and its semantic connections with other words in the dictionary of this language (Apresyan, V. - Apresyan, Yu. Babaeva - Boguslavskaya - Galaktionova - Glovinskaia - Iomdin - Krylova Levontina - Ptentsova - Sannikov - Uryson, 2010, pp. 18 - 19). "Active" character of dictionaries, i.e. a dictionary entry containing as full as possible information about a word, including paradigmatic and syntagmatic aspects, lexical and syntactic cooccurrence range, allows the latest researches to turn back to the issues of inclusion of encyclopaedic information into a dictionary definition area (see e.g.: Grigorovich, 2013).

\section{DICTIONARY USERS: ANTHROPOCENTRIC, COGNITIVE AND PRAG- MATIC ASPECTS}

Contemporary practical lexicography has begun to focus on the user. Prof. Valerij P. Berkov, for instance, outlines two principles for making a bilingual dictionary: maximum information in minimum space without inconvenience to the reader, and maximum consideration of the reader's interests (Berkov, 2013, p. 13).

Traditionally, the usability of a dictionary depends on various criteria but the most important of all is how easy it is to search for information. The authors of The Oxford Guide to Practical Lexicography, Beryl T. Atkins and Michael Rundell, point out that when making a dictionary one should remember that dictionary space is limited and that a dictionary is a peculiar ecosystem, all parts of which are interconnected. If you have a clear idea of who your user is and what they want from their dictionary, you stand a good chance of achieving the right fit between dictionary type and user need (Atkins \& Rundell, 2008, pp. 20, 23).

L. V. Shcherba's idea of active and passive dictionaries is widely accepted in contemporary lexicography. In his classic textbook, A Handbook of Lexicography: Principles and Methods of Dictionary Making (Svensén, 1987), Swedish researcher and dictionary maker Bo Svensén considers the primary needs of a dictionary user. He considers four primary types of language use: reading, writing, listening and speaking. Each of these uses requires a dictionary for different purposes - to find the meaning, spelling, pronunciation, synonyms, usage and etymology of a word.

When a user refers to dictionaries in their native language, for instance a definition dictionary of this language, particular needs are actualized: when reading in a native language the dictionary will not be used to look up spelling or cooccurrence as it is already given in the text. In this case the dictionary user will be looking up the meanings of words and expressions. When writing, a dictionary user 
who is a speaker of the language will be looking up grammatical features of the words and peculiarities of their use (stylistic peculiarities) whereas meanings of words and expressions will only be in demand if a dictionary user doubts his/her knowledge of the meaning of a certain word. For listening and speaking in the native language the speaker will need a native language dictionary to a lesser extent.

When using a bilingual (translation) dictionary the languages which the dictionary translates from and to are critical: from native into foreign or vice versa. If, for instance, a Swede is translating from French into Swedish, he will not be looking up language structures, usage of words and collocations or the stylistic features of Swedish words and expressions. The pronunciation of French words will be of interest to him only for interpretation. He will only need to find grammatical features of French words when translating into French. The same happens when there are several translation equivalents in a dictionary entry: when translating into Swedish, a Swedish-speaking user will have fewer doubts about the correct word whereas when translating into French the selection of synonyms in a dictionary entry will be crucial for him. This is why, as Svensén (following Shcherba) claims, users need four translation dictionaries: a Swede needs a passive dictionary to understand French text and an active dictionary to reproduce French text; a Frenchman needs a passive dictionary to understand Swedish text and an active dictionary to reproduce Swedish text. This seems to go without saying, but, in the opinion of Svensén it is not systematically taken into account by dictionary makers, often because it is unprofitable to publish four dictionaries. This is why, for instance, a French-English dictionary is intended for Frenchmen who produce English text and for Englishmen who read a French text. Quite often pairs of dictionaries (French-English and English-French, for instance) are combined into one volume giving users a chance to 'have their cake and eat it' without achieving the required aim. For dictionaries of 'minor' languages, such as Swedish, producing four dictionaries is hardly feasible because making such dictionaries takes a lot of time and money.

The user of a dictionary of a foreign language demands all kinds of information: the spelling and pronunciation of individual words, collocations and their pronunciation. Dictionaries intended for speakers of a language and for those who study it also show some differences. In the latter case, there is a greater need for information about the grammatical characteristics of words, their connotations and usage, including stylistic features. In both cases it is important to take into account that the level of the language used in any definition of a word in a dictionary entry should match that of the user, or else they will not understand it.

Some difficulties arise when making dictionaries of foreign words for a user who is studying a language because some of the information can be in the foreign language and some of it in the user's native language. Such dictionaries are published in Sweden in the framework of the LEXIN project (Lexikon för invandrare dictionary for immigrants). 
B. Svensén gives interesting facts about how the needs of dictionary users depend on their spheres of language use. Research carried out by D. K. Barnhart, Henri Béjoint and Reinhard Rudolf Karl Hartmann showed that a user needs definition dictionaries of his/her native language primarily to look up the meaning of a word and then for spelling, pronunciation, synonyms, usage and etymology. Definition dictionaries of a foreign language are needed first of all to find the meaning of a word and to determine its grammatical features, and then to search for synonyms, spelling, pronunciation, usage and etymology. Bilingual dictionaries (from foreign to native) need to define the meaning of a word and then to specify its grammar features, word collocations (usage context), synonyms, spelling, pronunciation, usage and etymology. In his research, D. K. Barnhart found that definition dictionaries of native language are most often used to look up idioms and words from different spheres of human activity and almost never to look up common content or functional words: the use is 'encyclopaedic'. R. R. K. Hartmann emphasizes that bilingual dictionaries (foreign to native) are most often used to look up functional words and culturally connoted lexis (realia words, non-equivalent lexis). Only $50 \%$ of users look for common vocabulary in such dictionaries. Svensén was surprised by the results obtained by $\mathrm{H}$. Béjoint: it turns out that definition dictionaries of foreign languages are used passively because the users are interested in the first place in the categories of words that are required for 'passive' use of language, that is, not for reproduction but for reading (idioms, 'encyclopaedic' words, culturally connoted lexis, abbreviations and slang expressions) (Svensén, 1987, pp. $10-16)$.

The typology of a dictionary is also determined by consideration of the psychology and sociological context of users: a dictionary description cannot but take into account the attributes and peculiarities of the human beings for whom it is written. In our modern age there has arisen a demand for dictionaries made for manmachine systems and it is the difficulty of creating these that reveals how fundamental the psychological aspect is. Indeed, in the opinion of P. N. Denisov, it alone distinguishes three types of dictionaries: for language speakers, for foreigners, and for computer-aided learning and translation. Due to their stage of cognitive development, children of preschool and school age also need special dictionaries, such as picture dictionaries. Adding sociological considerations results in the lexicographer having to take into account the psychological peculiarities not of an abstract man, but of a particular - and first of all social - one: a representative of a certain culture, a certain society, a speaker of a certain language (Denisov, 1980, pp. $210-211)$.

The basis for the description of words in a dictionary is to focus on the addressee. The addressee, that is, the dictionary user, is a certain universal unit, idealized in the dictionary maker's mind. Denisov suggests several principles for a definition, some of which - regularity, economy, simplicity, fullness - are often 
relatively easy to achieve, but the efficiency of a description is more nebulous, in particular because it is connected with eagerness to build a dictionary entry in form of an algorithm so that reading an entry in an active dictionary (a dictionary for speech synthesis) would result in correct usage of the described word in speech, and in a passive dictionary (a dictionary for speech analysis) it would gallow understanding of the exact meaning of a word in a context (Denisov, 1980, p. 215).

The Oxford Guide to Practical Lexicography presents different types of dictionary users. The authors claim that the way to make the dictionary required is to study the needs and skills of the user. Dictionary makers must clearly understand who will use the dictionary, for what purpose and what skills they possess. In order to decide which group the user belongs to, they should answer the following questions:

User type - Which of the following groups does the user belong to: an adult, a young child or a schoolchild? If they study the language, is it at beginner, intermediate or advanced level? Are they a general user or a specialist (if so, in what field)? What are the user's aims: learning, personal or professional?

Usage type - Why does the user need the dictionary? Is it for general purposes (looking up meanings of unknown words, checking spelling or pronunciation, solving crosswords); study of a particular subject; language studies; translation from one language to another; making text in a language; preparation for written or oral examination?

Skillset - What skills does the user already have? Do they have knowledge of peculiarities of the lexical and grammatical structure of languages in general and a certain language (languages) in particular? Are they able to use dictionaries in general?

It is very important for publishers, teachers, high school researchers and lexicographers to have information about how potential users use a dictionary, what they like and what they do not like about dictionaries, and what their expectations are. Monitoring can be done in various ways, for instance by collecting statistics from websites created for different types of users (Atkins \& Rundell, 2008, pp. 28-33).

$\mathrm{S}$. Landau underlines the importance of taking into account the status of a user, emphasizing that the person who needs a monolingual dictionary will be one studying the language in a country where it is widely spread and is the native language of part of the population or used as a lingua franca (Landau, 2001, p. 8).

User type is even more important for dictionaries such as those aimed at learners. Learner's dictionaries are usually divided into two groups based on their addressee: 1) dictionaries for foreigners (i.e. those to whom this language is foreign/ not native); 2) dictionaries for native speakers who study their native language as a subject (schoolchildren and students). B. Svensén includes these dictionary types in various oppositions: dictionaries for general use versus dictionaries for study; dictionaries for adults - dictionaries for children. The specific feature of dictionaries for study purposes is that users of such dictionaries have limited possibilities to use 
the dictionary contents. The aim of study dictionaries is to serve as an effective auxiliary means of communication. Dictionaries for children should not be just short versions of dictionaries for adults (Svensén, 1987 p. 20).

An important feature of the COBUILD learner's dictionaries published by Collins, according to Ladislav Zgusta, is user-friendly definitions. This userfriendliness, according to him, is expressed in different ways, including how the dictionary maker words a definition. For instance, instead of using a formal wording for a definition of to scold, the author uses a structure with you ('If you scold someone, you speak angrily to them because they have done something wrong.'). Another peculiar feature of the user-friendly definitions in COBUILD dictionaries is the orientation towards the living experience of a speaker, his/her knowledge of the world. If a building is defined as a structure with a roof and walls and a pyramid as an ancient stone building, then the dictionary maker leans on the user's knowledge that some building have roofs while others may not and that a pyramid has no roof. Thus, Zgusta follows this example by presenting a prototype for a dictionary definition (Zgusta, 1992, pp. 4 - 5; see also Atkins \& Rundell, 2008, p. 419). For a learner's dictionary, in the opinion of Landau, it is important to show not only what a word means, but also how it is to be used (Landau, 2001, p. 9).

From our point of view, an important point is that any form of dictionary (printed, electronic or on-line) needs to have selection criteria for the information used in an entry. The formula 'Explain, don't "define": you have to tell users what people really mean when they use a word' (Atkins \& Rundell, 2008, p. 451) can and should be critically reviewed. It is evident that the primary factors guiding the selection of information are the type of dictionary and the needs of a user. This is especially important when making of dictionaries of endangered languages.

\section{ENDANGERED-LANGUAGE DICTIONARIES: THE PRIMACY OF THE USER}

Linguistic papers view the issues of lexicographical work with endangered languages from different perspectives. Ulrike Mosel describes the difficulties of documenting an endangered language of Papua New Guinea and issues connected with this process. The principal differences between making a dictionary for a major language and an endangered language, in her opinion, are that the documentation of endangered languages is not a business and that the database maker is not a speaker of the language. A dictionary of an endangered language is usually made by a teacher or a missionary who has regular contact with the language speakers and lives among them or often visits them. A dictionary is most often a by-product of scientific research. Mosel states that the purpose of an endangered-language dictionary is not translation or language study, but description with the aims of scientific research and revitalization of the language. But in this case too the making of a dictionary should 
be preceded by comprehension of who will use it and for what purpose: that is, the dictionary should address the interests of both speakers and researchers. The best option in this instance is to make two dictionaries: one meeting the needs of language speakers and the other meeting the needs of the researcher and his/her scientific work. But if it is not possible to make both, the first has priority. Making an endangered-language dictionary is connected with several issues that are crucial for researchers, such as choice of the basic dialect for the dictionary, definition of dictionary type, and decisions about spelling words. Speakers of the language should decide which dialect is to be primary for the dictionary, but if this right is given to the researcher, he should decide based on the number of speakers of each dialect, their age, and how the dialect is used for different functions. If an endangered language has no standardized orthography, the dictionary maker should consult the language community. When doing so, they should remember that this issue is often political. Despite the fact that alternative spellings can make a dictionary bulky, sometimes keeping such alternatives cannot be avoided (Mosel, 2011).

In focusing on these issues, in our opinion, researchers often overlook some of the user-centred aspects of creating an endangered-language dictionary.

Our work on making of dictionaries of the Saami language - dictionary of spiritual culture lexis, traditional trades and husbandry lexis and zoonyms in Kildin Saami (Ivanishcheva \& Bakula, 2013; Ivanishcheva \& Ershtadt, 2014; Ivanishcheva \& Mitina, 2015) - led to some conclusions regarding the peculiarities of a potential user of these dictionaries.

The Saami are indigenous small-numbered people of the North that have been divided historically and presently live in four countries: Russia, Finland, Norway and Sweden. The Russian Saami (the Kola Saami) live mainly on the Kola Peninsula which lies within the administrative unit of Murmansk. The language of the Kola Saami (the Kola Saami language) has four dialects: Kildin, Ter, Akkala and Skolt Saami. Kildin is the most widespread dialect.

According to the 2010 Russian population census (Russian Population Census, 2010) there are 1771 Saami in Russia (urban population - 787, rural population 984), of whom 1599 live in the Murmansk region. The traditional Saami trades are reindeer husbandry, hunting, fishing and foraging. It is reindeer husbandry that lies at the root of the ethnographic uniqueness of the Saami. Analysis of the contemporary sociolinguistic situation shows that the Kola Saami language is critically endangered and this threat is connected to the fact that the Saami have been breaking away from traditional trades and ways of life, they are becoming dispersed, there is a lack of educational opportunities, the demand for the Kola Saami language among the Saami is low and the Russian language has had a long-term impact on it. In addition, the Kola Saami did not have a writing system until recently. With the language being the guardian of spiritual and material culture, the Saami may lose the knowledge of their culture as well as the language itself. 
The dictionaries of the Saami lexis listed above achieve the primary objective of our research - they record the present state of the Saami language within the language community. In doing so, they perform a very important function preserving components of the traditional world outlook which encapsulates the northern ethnos. The lifestyle of indigenous small-numbered people is determined mainly by three factors: natural conditions, the distribution of the population and type of economy. The latter two determine the culture. This knowledge of such peoples reflects a more archaic, fundamental human attitude to the world, from the perspective of the senses and the utilitarian values of folk culture.

The experience of making dictionaries of the Saami language showed that dictionaries of endangered languages have their own specificity, one which lies in their users, wordlists and definitions.

The specificity of a potential user of our dictionaries is that his/her knowledge of the native language is problematic and, should the dictionary be bilingual, the user will have to have a command of at least one of the languages - Russian or Kola Saami. The majority of the Kola Saami have a command of Russian and just some of them have a command of the native Saami language. It is estimated that Kildin Saami is spoken by 700 people, but this number is rather optimistic. According to E. Scheller, there are likely to be 100 active speakers: these are people fluent in the Kildin Saami language and using it on different levels. They form $5 \%$ of the Saami living in Russia in 2010. Around 200 speakers are regarded as passive speakers: they understand everything or pretty much everything and they are able to speak Kildin Saami but do not for various reasons (Scheller, 2010).

As a result our dictionaries are translation (bilingual) dictionaries, i.e. they contain an original Saami word and a dictionary entry consisting of a translated equivalent most often in the form of a description. Besides the Saami lexis, equivalents, comments and explanations are given in Russian. But the focus of attention in the dictionaries is not on a word's grammatical features but on a culturological commentary which reflects the background knowledge of a speaker as shown in the following examples from out dictionaries of the Saami lexis:

вуунхэй - a matchmaker, matchmaking. Matchmakers were usually close relatives, but sometimes they were chosen from outsiders, peers, friends. In the Pazretsk village a male matchmaker was called 'a thread spinner' or 'a coachman'. The origin of the first name lies in the matchmaker's duty to ask the bride questions, to praise her, to arrange things; and 'a coachman'because he invited relatives to the wedding and served wine to all of them. A female matchmaker was also called ' $a$ thread spinner' because she praised the bride and prepared her for the wedding. Their presence in the church was not compulsory as they didn't have any duties there. N. N. Kharuzin assumes that the matchmakers were called 'thread spinners' because they started spinning threads before matchmaking. All the relatives of the bride and the groom were also considered to be matchmakers for each other. 
A matchmaker could be either a middle-aged man or a middle-aged woman (Ivanishcheva \& Bakula, 2013, p. 69).

ледник - an icehouse for storage of fish, a natural crevasse or a buried structure which was filled with ice in springtime. The ice was brought from frozen lakes where it was broken off using ice picks. Throughout the summer, from May to July, the ice slowly melted preserving the fish very well (Ivanishcheva \& Ershtadt, 2014, p. 159).

nальтэсь - a wolf. When Saami hunters saw a wolf they tried to exhaust it by chasing it on skis and stabbing it with stakes. Should a wolf be able to resist and left traces when trying to hide, they would finish it off with a crossbow, a bear spear or a javelin. Another way of wolf hunting is to make a trap. Wolves were driven into these traps and killed by lead bullets fired from hand cannons. The Saami have always had at war with wolves because large wolf packs cause great damage to their reindeer herds. Olaus Magnus speaks about leg-hold traps which crushed wolves' legs at the moment they bore down on food placed next to it. Wolf skins were articles of barter for trade with the Swedes. The Saami exchanged wolf skins for copperware and cheap fabric made by Swedish peasants. Sometimes wolf fur was used for mittens. Mittens had fur on the outside (Ivanishcheva \& Mitina, 2015, p. 56).

As can be seen from the examples, definitions in our dictionaries are of a bilingual kind: they consist of a word with a culturological commentary to the translated equivalent. The primary purpose of our dictionaries is the preservation of unique facts about the culture, and language as part of the culture, of an indigenous minority. That is why the first part of each definition in the dictionary is a notion (a concept), rather than a single word (see e.g.: Alefirenko, 2015; Cukan, Korina \& Lenovsky, 2014).

The content of definitions in dictionaries such as ours, of indigenous smallnumbered people's languages, reflect the everyday level of cognition: the immediate personal experience of people. Although this is more individual than a scientifically described level, using such an approach has advantages which lie in the variety of solutions and the width of search that is possible. The dictionaries of the Kola Saami lexis reflects this situation: where there is no live speaking environment - because there are limited opportunities to use the language in private and public life, most active speakers are seniors, and speakers are separated from the material and spiritual culture of the language habitat - it is natural to turn to the cognitive rather than the communicative essence of the background knowledge. In such cases the typical ways of finding out the background knowledge of a language speaker (interviews, analysis of various dictionary entries and examination of fiction and journalism) cannot be used to their full extent. A researcher must therefore record all the knowledge of a language speaker making no differentiation between the personal and the social: the recounted personal experience of a language speaker who is an informant has to be considered typical and usual because tsuch knowledge is recorded only in the social environment in which he grew up. 
Our field studies of the Saami language showed how different the knowledge of realia can be for different speakers. Comparison of field data and Saami language dictionaries compiled by Georgij M. Kert (Kert, 1986) and by Nina A fanasjeva et al. (Afanasjeva, 1985) revealed some discrepancies in the age ranges for a reindeer name. Cf.: вундел - reindeer doe of two years (Anna Nikolaevna Yurjeva, native Kildin Saami speaker) and вуннял - reindeer doe of three years (Anna Nikolaevna Yurjeva, native Kildin Saami speaker); воджемь - young reindeer doe of three-four years (Anna Nikolaevna Yurjeva, native Kildin Saami speaker) and ваджь reindeer doe of three-six years, fawned once (Kert, 2003, p. 54), важь - reindeer doe (three-year-old reindeer doe after first fawning) (Afanasjeva, 1985, p. 33). These discrepancies cannot yet be explained.

Our dictionaries of the spiritual and material culture of the Saami are of mixed type - they are learner's dictionaries and linguoculturological dictionaries. On the one hand they describe a culture which is foreign to a Russian-speaking user - and indeed they contain data that is often unknown even to most Saami culture bearers. On the other hand, the dictionaries are also intended for Saami who have no command of the native language. It is this duality that makes makes the dictionaries of indigenous minorities whose language is critically endangered specific.

\section{CONCLUSION}

A dictionary of an endangered-language lexis is a unique lexicographical product. When making such dictionary one should take many factors into account (the purpose of the dictionary, grammatical features of the language, spelling options in the absence of a standard, etc.), but special attention, in our opinion, should be paid to the dictionary user - the bearer of this culture and speaker of this language: his/her experience and knowledge (or lack of knowledge) of his/her own culture and language and his reasons for using the dictionary. Such a dictionary therefore is both a learner's dictionary and a linguoculturological dictionary: alongside the translation in the basic part of the dictionary there is a culturological commentary that as fully as possible reflects the knowledge of language speakers, derived from interviews with living speakers, ethnographical sources, texts of fiction and folklore. Such a dictionary serves as both a textbook of native language and culture and an encyclopaedia of folk wisdom, thus putting into practice the anthropocentric, cognitive and pragmatic approach to lexicographic description of culture.

\section{References}

AFANASJEVA, Nina - KURUCH, Rimma - MECHKINA, Ekaterina - ANTONOVA, Alexandra - JAKOVLEV, Leonid. - GLUCHOV, Boris: Saami-Russian Dictionary. Са̄мь-Рӯшш Соагкнэһкь. Moscow: Russkij Jazyk 1985. 568 pp. 
ALEFIRENKO, Nikolaj: Language as a State of Ethno-Cultural Consciousness. In: XLinguae Journal, 2015, Vol. 8 Issue 3, June, pp. $3-18$.

APRESYAN, Valentina - APRESYAN, Yurij - BABAEVA, Elisaveta - BOGUSLAVSKAYA, Olga GALAKTIONOVA, Irina - GLOVINSKAIA, Marina - IOMDIN, Boris - RHYLOVA, Tatiana - LEVONTINA, Irina - PTENSOVA, Anna - SANNIKOV, Andrej - URYSON, Elena: Prospect of Active Dictionary of the Russian Language. Ed. Yu.D. Apresyan. Moscow: Jazyki slavjanskih kul'tur 2010. 784 pp.

APRESYAN, Yurij: Lexicographical Conception of the New Unabridged English-Russian Dictionary. In: The New Unabridged English-Russian Dictionary. Of 3 Volumes. Ed. Yu.D. Apresyan and E.M. Mednikova; 3rd edition; reprint. Moscow: Russkij Jazyk 1999. Vol. 1, pp. 6 - 17.

ATKINS, B. T. Sue - RUNDELL, Michael: The Oxford Guide to Practical Lexicography. N.Y.: Oxford University Press 2008. 540 pp.

BERKOV, Valerij (ed): Stor norsk-russisk ordbok. Oslo: Kunnskapsforlaget 2003. 1605 pp.

CUKAN, Jaroslav - KORINA, Natalia - LENOVSKY, Ladislav: Culture - Language - Identity (problem of relations). In: XLinguae Journal, 2014, Vol. 7 Issue 4, October, pp. 21 - 32.

GAK, Vladimir: Bilingual Dictionary of an Active Type. In: Language - System. Language Text. Language - Ability. Ed. Yu. Stepanov. Moscow: IRYA RAN 1995, pp.53 - 62.

GAO, Jun: Basic Cognitive Experiences and Definitions in The Longman Dictionary of Contemporary English, In: International Journal of Lexicography, 2013, Vol. 26 Issue 1, March, pp. 58 - 89.

GRIGOROVICH, Leonid: Encyclopaedic Details in "New Definition Dictionary of Russian Standard Language with Extended Word Details". In: Současná slovanská lexikologie a lexikografie / Contemporary Slavic Lexicology and Lexicography. Prague, 2013, pp. 283 - 289.

DENISOV, Petr: Lexis of the Russian Language and Principles of its Description. Moscow: Russkij Jazyk 1980. 251 pp.

IVANISHCHEVA, Olga - BAKULA, Viktoria: Dictionary of Kola Sami Spiritual Culture Lexis. Murmansk: Murmansk State Humanities University 2013. 222 pp.

IVANISHCHEVA, Olga - ERSHTADT, Alexandra: Dictionary of Kola Saami Traditional Trades and Husbandry Lexis (A Case Study of Kildin Saami). Murmansk: Murmansk State Humanities University 2014. 249 pp.

IVANISHCHEVA, Olga - MITINA, Yulia: Zoonymikon in the Kildin Saami Language: Learner's Culturological Dictionary. Murmansk: Murmansk State Humanities University 2015. 108 pp.

KERT, Georgij: Saami-Russian and Russian-Saami Dictionary: Handbook for Primary School Children. Leningrad: Prosveshchenije, Leningrad Division 1986. 247 pp.

LANDAU, Sidney I.: Dictionaries: The Art and Craft of Lexicography. 2nd edition. Cambridge: Oxford University Press 2001. 477 pp.

MELCHUYK, Igor - ZHOLKOVSKY, Alexandr: Explanatory and Combinatory Dictionary of Contemporary Russian Language. Practice of Semantic and Syntactic Description of Russian Lexis. Vienna: Wiener Slavistischer Almanach 1984. 992 pp.

MOSEL, Ulrike: Lexicography in endangered language communities. 2011. Accessed on http:// www.linguistik.uni-kiel.de/sldr/stuff/CUP_Mosel_Lexicography140809.pdf:

NKOMO, Dion: An African User-Perspective on English Children's and School Dictionaries. In: International Journal of Lexicography, 2015, first published online August 28. Accessed on: http://ijl. oxfordjournals.org/content/early/2015/08/28/ijl.ecv025.abstract

RUSSIAN POPULATION CENSUS: Final Data of the Russian Population Census in 2010. Accessed on: http://www.gks.ru/free_doc/new_site/perepis2010/perepis_itogi 1612.htm

SCHELLER, Elisabeth: Situation of the Saami Languages in Russia. In: Science and Business on Murman, 2010, No. 2(69), pp. 15 - 27.

SCHRYVER de, Gilles-Maurice - PRINSLOO, D. J.: Do dictionaries Define on the Level of their Target Users? A Case Study for Three Dutch Dictionaries. In: International Journal of Lexicography, 2011, Vol. 24 Issue 1, March, pp. 5 - 28. 
SHCHERBA, Lev: Teaching Languages at School: General Methodology Issues: Training Aid for Students of Linguistics Department. 3rd ed., revised impression. St.-Petersburg Filologicheskij fakul'tet SPbGU; Moscow: Academia 2002. 160 pp.

SHCHERBA, Lev - MATUSEVICH, Mikhail: Russian-French Dictionary: 14th edition. Moscow: Russkij Jazyk 1993. 837 pp.

SVENSÉN, Bo: Handbok i lexikografi: Principer och metoder i ordboksarbete. Stockholm: Esselte Stadium och Tekniska Nomenklaturcentralen 1987. 279 pp.

ZGUSTA, Ladislav: Manual of Lexicography. The Hague/Paris: Mouton 1971. 360 pp.

\section{Resumé}

\section{SLOVNÍKY VÁŽNE OHROZENÝCH JAZYKOV: SO ZAMERANÍM NA POUŽÍVATELA}

Ciel'om štúdie je dokázat', že v prípade zanikajúcich jazykov je nutné zohl’adňovat' špecifiká používatel'a ich slovníkov z pozície antropocentrického a kognitívno-pragmatického prístupu. Štúdia ukazuje, že pri zanikajúcich jazykoch je orientácia na použivatel’a slovníka zvlášt’ aktuálna. Pritom je nevyhnutné brat' do úvahy, že použivatel' slovníka je síce predstavitel'om príslušného etnika, deklaruje svoju etnickú príslušnost', rešpektuje tradície svojho národa a zachováva si svoju kultúru, často však neovláda rodný jazyk alebo ho ovláda len v obmedzenej miere. Takýto nositel' jazyka pozná určitú terminologickú základňu, ktorá je nutná pre ovládanie remesiel, a takisto používa hovorový jazyk s obmedzenou slovnou zásobou. Účelom slovníka v takejto situácii je nielen uchovat', čo ešte zostalo v pamäti nositel’ov zanikajúceho jazyka a kultúry, ale aj revitalizovat tieto vedomosti. Podl’a autorky musí súčasná lexikografia zohl'adňovat' pri tvorbe slovníka niekol'ko faktorov: pre koho sa slovník zostavuje (antropocentrický aspekt), aké sú ciele používania príslušného slovníka (pragmatický aspekt) a aké zručnosti potrebuje používatel' slovníka na jeho používanie (kognitívny aspekt). Tieto faktory, konštatované v lexikografii ktoréhokol'vek jazyka, majú v prípade zanikajúcich jazykov svoje špecifiká. Autorka sa domnieva, že pre zanikajúce jazyky je v uvedenej súvislosti najaktuálnejší taký typ slovníkov, ako je študijný a lingvokulturologický (slovník aktívneho typu). V štúdii sa zdôrazňuje, že slovníky laponského (sámskeho) jazyka na jednej strane najčastejšie prinášajú informácie, ktoré nie sú známe dokonca ani nositel’om laponskej kultúry, a na druhej strane sú určené aj pre laponského použivatel’a neovládajúceho jazyk svojho etnika. To určuje špecifikum slovníka vrátane faktu, že základnú čast’ slovníka spolu s prekladom, tvorí kulturologický komentár, čo najúplnejšie odrážajúci extralingvistické znalosti nositel’a jazyka. 